ore-lead are concentrations of rock-lead, it is shown that the age of the earth is not far from $3,000 \mathrm{~m} . \mathrm{y}$. ; that corresponding to an age of exactly $3,000 \mathrm{~m} . \mathrm{y}$. the constitution of the earth's primeval lead is about

$$
\begin{array}{cccc}
\mathrm{Pb}^{204} & \mathrm{~Pb}^{205} & \mathrm{~Pb}^{207} & \mathrm{~Pb}^{238} \\
1 & 12 \cdot 50 & 14 \cdot 28 & 31 \cdot 82
\end{array}
$$

and that the most probable sources of ore-lead (with the provisional exception of the Joplin ores) are granitic rocks now containing, on average, about $3.3 \times 10^{-6} \mathrm{gm}$./gm. uranium, with the ratio thorium/ uranium about $3 \cdot 8$. It is hoped to publish a detailed account of the investigation elsewhere.

${ }^{1}$ Nier, A. O., J. Amer. Chem. Soc., 60, 1571 (1938); Nier, A. O., Thompson, R. W., and Murphey, B. F., Phys. Rev., 60, 112 (1941).

2 Holmes, A., Econ. Geol., 32, 764 (1937); and 33, 829 (1938).

- Fvans, R. D., and Goodman, C., Bull. Geol.Soc. Amer., 52, 459 (1941); Keevil, N. B., Amer. J. Sei., 242, $309^{-1944) .}$

- Bastin, E. S., et al., Geol. Soc. Amer., Spec. Pap., 24, 131 (1939).

'Wegmann, C. E., Medd. om Gronland, 113 (No. 2), 135 (1938).

${ }^{6}$ Sandell, E. B., and Goldich, S. S., J. Geol., 51, 99 and 167 (1943).

'Rosenqvist, I. Th., Amer. J. Sci., 240, 356 (1942).

${ }^{8}$ Hevesy, G., and Hobbie, R., Nature, 123, 1038 (1931).

- Goldschmidt, V.M., Skr. Norsk. Videns. Akad., Oslo, I Mat.-Nat. Kl., 1937, No. 4, 94 (1938).

10 KeeviJ, N. B., Econ. Geol., 83, 685】(1938).

\section{INDUSTRY AND RESEARCH}

$\mathrm{O}^{\mathrm{N}}$ a number of occasions during the past year or two, the subject of research in industry in Britain has been ventilated and discussed at confer. ences arranged by various organisations. Although the attendance at these conferences has included some industrialists it is, to some extent, true that the discussions have been directed at industry; and that the general background of the conferences has included an assumption that industry had yet to be fully convinced of the virtues of applied science and that the vital relation between scientific research and industrial progress had yet to be completely appreciated. It was, therefore, fitting and timely that at a conference arranged by the Federation of British Industries held in the Kingsway Hall, London, on March 27 and 28, 1946, industry should have been given the opportunity of expressing its own views on this subject and of indicating the extent of its appreciation of the importance of scientific research. The conference was remarkable in that no less than twelve hundred delegates, drawn from all branches of industry, accepted invitations to attend it, and the Federation is to be congratulated on this successful outcome of its venture. Even more solid grounds for congratulation to the organisers, and to Sir William Larke in particular, were provided by the genuinely enthusiastic atmosphere and by the relevant and lively nature of the discussions which the conference evoked. There can no longer be any room for doubt as to the interest of industrialists in research.

The chairmanship of each of the four sessions of the conference was significant. At the introductory session on "Science," Industry, and the Community", the presence in the chair of Sir Clive Baillieu, president of the Federation of British Industries, provided an indication that this was a conference of industrialists. In passing it may be remarked that the opening of the discussion at this session by Sir Robert Robinson, president of the Royal' Society, was symbolic of the complete dependence of the industrial application of science on the successful prosecution of fundamental, academic research. The Government's interest in industrial production was indicated by the presence of Mr. John Wilmot, Minister of Supply and Aircraft Production, at the second session, at which "Scientific Research and Production" was considered. The Minister of Supply shares with the President of the Board of Trade responsibility for the 'health of industry' in Great Britain. Further, the Government's realization of the need for adequate research was exemplified by the chairmanship of the Lord President of the Council, Mr. Herbert Morrison, at the third session, on "Scientific Research and Expansion"; his presence served as a reminder that the channel through which the benefits of the Government's practical interest may reach industry is provided by the Department of Scientific and Industrial Research. Finally, the continuity of Government policy in this matter was illustrated by the chairmanship at the fourth session, on "The Application of Research in Industry", of Sir John Anderson, formerly Chancellor of the Exchequer.

It will be convenient to review the conference under four heads provided by the resolutions submitted by Sir William Larke in his concluding address :

(1) "This conference recognizes that to ensure a reasonable standard of living the competitive power of British Industry must be firmly secured. To achieve this object it is essential to maintain technical pre-eminence in design, quality and production. This conference therefore urges every industrial concern to make the greatest possible use of scientific knowledge directly it becomes available."

The experience gained during the War of the amazing effect which a planned and co-ordinated scientific effort can have, not only on the volume of production but also on the ability to produce articles which exactly meet the requirements of the user, has been the most potent factor in spreading the gospel of the efficacy of applied research, and in this respect has created a conviction which innumerable confer. ences would never have achieved. The effects of the War on the industrial position of Britain have, however, been such as to make the translation of belief into concrete action a matter of desperate urgency and to render useless any slow and gradual introduction of science into the industrial framework.

There are many large industrial concerns with wellestablished comprehensive research departments, and the conference was given the benefit of the experience gained by the heads of some of these departments concerning the impact of research on the matters covered by the resolution. Exported goods, and, for that matter, goods for home consumption, must be of the highest quality. The use of the best and most suitable materials is vital to quality; hence research into the properties of materials, side by side with the search for new materials having particular properties, must be continuously pursued. Competitive power is dependent on maintaining low production costs. It is a fallacy that the empiricism and the trial-anderror methods of non-technical staffs really lead to economy in production. The scientific control of processes is the only certain way of reducing production costs to a minimum, and, incidentally, the data provided by scientific recording and control may well provide the background from which economic modi. fications of processes may emerge.

Again, in this highly technical and mechanical age, no industry can remain in the competitive market 
which does not constantly review the efficiency of its plant and the efficacy of its processes. Modernization can only be achieved by constant research into such matters as the processes of combustion, the mechanism of heat transfer, the behaviour of metals under conditions of high temperatures, the causes of corrosion and abrasion of materials, and mechanical operating efficiency.

Finally, it is not enough merely to conduct research. It is essential that the means should exist whereby the conversion of the results of research into production should proceed as smoothly and efficiently as possible. In this respect consideration must be given to inter-departmental relations, and care must be exercised to ensure that the boundaries of research and production are not so narrowly defined as to include no common territory.

(2) "Every industrial unit should include a qualified official or officials with the specific duty of following general scientific technical developments and literature and of bringing to the immediate notice of the executive authority all matters related to the processes or products of the concern."

It is an unfortunate fact that in many industrial concerns the executive authority has no link with the scientific world, and has no means of assessing the relevance of the happenings in that world to its processes and products. The contributions to fundamental scientific knowledge by workers in Great Britain have been outstanding; the application of advances in scientific knowledge to the needs and requirements of industry have all too frequently been made elsewhere. The protection of these applications by patents has placed British industry at a serious disadvantage. The main reason for this state of affairs has been the lack of liaison between industrial managements, which shape industrial policy, and scientific establishments. Certainly a much more effective liaison exists in some other countries.

There is, then, an urgent requirement for practical interpretation of the trends of science to industrial executives, and this requirement cannot be adequately met by anything less than the inclusion in an industrial unit of a qualified official specifically charged with the duty of correlating the findings of scientific research with the firm's interests. Moreover, the emergence of new industries, or the considerable extension of old industries, following new advances in scientific knowledge, is dependent upon an individual or individuals grasping the possibilities of application, and by the belief in these possibilities being backed by those in executive authority. Obviously the existence in industrial units of officials charged with keeping an ever-watchful eye on the possibility of potential applications would facilitate the reaping of the practical harvests of science and would markedly shorten the inordinately long timelag between discovery and application which has existed in the past.

In this connexion it is relevant to direct attention to the beneficial results which have followed the inclusion in executive authorities of qualified technicians and men of science. Such a member of the executive might well be the co-ordinating official referred to above; but in any event the technicalities of this age and the impact of science on industrial processes would seem to render the inclusion of science and technology among the managerial assets not only reasonable but also essential.
(3) "This conference holds that the application and use of science in daily industrial life in this country will require the progressive growth of industrial research facilities for both established and new industries. It urges every industrial concern to join and make the fullest use of its appropriate Research Association and, where practicable, to establish its own research department."

The problem of wedding science and industry in Great Britain is rendered the more difficult by the fact that, in the main, the average industrial unit is a small one, with severely limited financial resourcés. The establishment of a comprehensive research department, costing, say, $£ 50,000$, with an annual maintenance expenditure of $£ 20,000$, is quite beyond the capabilities of the great majority of industrial firms. The research association movement has had its critics; but a review of the past twenty-five years and consideration of the present situation compels the opinion that few wiser governmental decisions were ever made than that which led to the formation of research associations. The research association must provide for the average firm the facilities for the prosecution of basic applied research without which no sure foundations can exist on which to make particular industrial applications of scientific knowledge. But the existence of a research association does not exonerate any firm from establishing some research facilities or from creating in some part of its works a research atmosphere. At the least this may mean that one young scientific worker will be employed by any industrial unit, who will keep in close contact with the research association and who will assist in the translation of the results of the association's work into workshop practice. The firm will be more fortunate which can afford to establish even the smallest of research departments, which, apart from its intrinsic value to the firm, will serve as a constant reminder that, in these days, industrial processes are not static.

The general acceptance, even of necessity, of cooperation in research as exemplified in the research association may have one important advantage. Great Britain has been sadly handicapped by the difficulty experienced by one industry of obtaining materials peculiar to its own needs from another industry in the manufacturing field of which the materials lie. The co-operative research ideal should include a system of inter-industrial co-operative research, planned on a wide scale and making use of Government, university, research association, and industrial research facilities, with the object of removing all industrial handicaps resulting from the use of materials which only approximate in their properties to those which are ideal. Scientific men forgather for purposes of discussion and interchange of information at the meetings of learned and tech. nical societies, and the largely increased employment of men of science in industry visualized by the conference, might well result in the creation of an atmosphere of inter-industrial sympathy and knowledge which would react most favourably on this wider co-operative effort.

(4) "This conference places it on record that an essential factor in pursuing these aims is the provision of increased facilities in educational establishments for training scientific and technical personnel and urges industrialists to stimulate such provision in their own field of interest." 
The main obstacle to the achievement of a full measure of research activity in industry is not to be found in any hostility to the scientific worker or in any sense of complacency in industry, but in the scientific man-power situation. A healthy industry requires that far more scientific workers should be trained in the future than in the past. The larger universities are already as large as is consistent with efficiency, and it follows therefore that increased facilities must be created by enlargement of the smaller provincial universities and by the establishment of technical educational institutions in industrial areas where no university or technical college exists.

The Government is alive to the situation and has established the machinery for reviewing and, it is to be hoped, remedying the existing state of affairs. The problem of providing adequate facilities for technical and scientific training includes the provision of sufficient and qualified teachers. Since, under the best conditions, the teaching staff of a technical institution should be in close contact with technicians and scientific men engaged in industry, it is highly desirable that the remuneration of the teachers should compare favourably with that received by their industrial colleagues; and, in fact, suitable teachers will not be forthcoming unless such is the case. The last clause of the resolution is important, for past experience has shown that when industry has interested itself in local educational matters and has supported the local education authority, the battle for the provision of technical educational facilities peculiar to local requirements has been more than half won. Whatever Government scheme for technical education is fortheoming, its application to particular areas will undoubtedly be influenced by a display of stimulating interest on the part of local industry.

\section{THE ROYAL ACADEMY, 1946}

\section{By DR. A. T. HOPWOOD}

British Museum (Natural History)

" $\mathrm{C}$ VRITICS have always been people less suscepA tible than other men to the contagion of art. For the most part they are able writers, educated and clever, but with their capacity for being infected by art quite perverted or atrophied." Tolstoy's diatribe against crities was inevitably brought to mind by the present Summer Exhibition at the Royal Academy. The first impression was disappointing, and the critic had to determine where the fault might lie. Subsequent impressions were no more favourable; it proved distressingly easy to spot artist after artist without recourse to the catalogue. Another source of disquiet was the obvious dependence of many exhibitors on French artists of a generation or so ago. Neither of these is a healthy sign : the first indicates a tendency to fixity of style, to painting to a formula, and the second a lack of originality. It seemed likely, therefore, that there might be something wrong with the exhibits after all.

Now Tolstoy propounded a muddled variant of the generally held view that the fruits of an artist's labours constitute a work of art only in so far as they convey his emotions to the spectator; he also held the opinion, more popular than ever in certain circles to-day, that "art should belong to the people". Hence his high opinion of the untutored peasant as a judge of art. If such indeed were the case, the artistic value of "Flower Piece" by E. Wadsworth (No. 665), or of "Objects in a Scene of Devastation" by H. A. Lunn (No. 657) could not be rated very highly, for, whatever may have been the emotions of the artists as they painted, they are completely hidden from the vulgar perception. On the other hand, "Girl in Grey" by J. B. Souter (No. 454) would obviously be of higher artistic value, because a picture of a pretty girl standing with one hand resting on the mantelshelf seems to tell its own story. The falsity of this reasoning is not immediately apparent. That Mr. Souter's painting is of considerable artistic merit arises, not from the subject, but from the artist's skill in drawing and design, and from his sense of colour, and that this is the real explanation is shown by his other picture, "Wood Wind" (No. 520 ), in which there is no pretty girl to disturb the judgment.

But there is another and more puritanical, more 'scientific' theory of art. More puritanical because the emotions are heavily discounted, more 'scientific' because there is an elaborate classification of the different types of artists ranging from the 'original architectural artist' down to the 'venal popular artist'. R. H. Wilenski, the author of this theory, holds that a work becomes a work of art when it has been honestly and competently passed by its author as having satisfied his aims. From this fact alone it possesses an intrinsic value according to the artist's position in the classified scheme. There is also an independent and acquired value which arises from the reaction of the spectator. It then becomes the critic's function to endeavour to explain the artist's aim, and not to describe his own emotions.

Clearly, the intrinsic value is something peculiar to the picture and personal to the artist, and the spectator must assume that each of the exhibits has been honestly approved by the artist as having the primary intrinsic value; but the critic's task is not made any easier thereby for he has to attempt to explain something which is personal to another. More especially is this true of the present show, which is stolen by a picture painted more than seventy years ago. "Hearts are Trumps" by Sir John Millais is an example of a mastery which to-day is practically extinct. To dismiss this picture as 'popular romantic art' is entirely beside the point ; it displays a knowledge and craftsmanship which are absent from the majority of the modern works, and those who affect to despise craftsmanship should remember Renoir's advice, "Be a good craftsman first of all ; that won't prevent you having genius".

Good craftsmanship I take to include good drawing and good design, as well as good painting, but all three are rarely to be found on one and the same canvas. The weakest spots are usually drawing and design. One example of good craftsmanship is "Shipyard at Palma in Majorca" by C. Muncaster (No. 467), another is "Life Study" by Erica Suttill (No. 482). On the other hand, there are many works which by reason of their heavy impasto cannot be regarded as good painting. This is not to say that the artist has not achieved what he set out to do, nor that the result is bad, but merely that heavy impasto affords lodgment for dirt and dust, and that one regrets a pleasant sketch such as "Chilham Mill" by James Doxford (No. 8) should carry within itself the seeds of its own decay.

As usual, there is a large number of flower pieces of varying merit, and nearly as many still lifes, 'still life with trimmings' as it were, but only on 